\title{
Effect of Demographic Changes on the Labour Supply in Lithuania and Poland
}

\author{
Magdalena Wysocka
}

University of Warmia and Mazury in Olsztyn

ul. M. Oczapowskiego 2, 10-719 Olsztyn, Poland

E-mail.magdalena.wysocka@uwm.edu.pl

cross'ref http://dx.doi.org/10.5755/j01.ee.32.1.25087

\begin{abstract}
Demographic changes are one of the variables impacting labour supply. When viewing the situation on labour markets, not only quantitative changes in the total population size are significant, but also changes in the population categorised by economic age groups. International research indicates that the population size is decreasing. These processes translate into labour markets experiencing deficiencies in labour force. To counteract and minimise these undesirable conditions, continuous monitoring and diagnosis of the status of labour resources is required. This paper aims to evaluate the impact of demographic changes in labour supply based on the example of the Lithuanian and Polish labour markets and to redefine the groups of people forming unused labour resources. To this end, both secondary and primary data were used. The former were derived from statistical reports originating from the analysed countries, while the latter were obtained from the author's own studies carried out among 200 respondents classified as unused labour resources. The research found that in the labour markets of both studied countries, very significant changes have occurred and will continue to occur, which may lead to the reduction in the productive-age population and to the increase in the post-productive-age population. The research has been carried out based on the systematic literature review methodology, which included theoretical and empirical research publications from 2000-2019, a diagnostic survey conducted among people classified as unused labour resources, as well as methods of descriptive statistics and induction. The literature review has demonstrated a shortage of studies on the subject of research, which makes the content of the paper a partial answer to the existing knowledge gap.
\end{abstract}

Keywords: Demographic Projection; Labour Force Participation; Labour Market; Population Ageing; Potential Labour Resources.

\section{Introduction}

For several years, significant demographic changes have been observed throughout Europe, resulting in an unfavourable population size and structure. In classifying the population by economic age groups, a gradual increase can be observed in the number of people of post-working age, which indicates population ageing. In 2017, the percentage of elderly in the European Union (EU), Lithuania and Poland was $19.4 \%, 19.3 \%$ and $16.5 \%$, respectively. According to the Eurostat projections, in 2050, the average value of the rate of ageing of all European Union countries will be slightly over $28 \%$. Such value is also forecasted for Lithuania, while in Poland this ratio will almost double and amount to over $30 \%$. The median age for the entire EU will be about 46 years, in Lithuania - 42 years, and in Poland it will rise from the current less than 40 years to almost 50 years (Glowny Urzad Statystyczny, 2014).

Studying the effect of demographic changes on the state of labour resources is not a new issue. Literature on the topic is abundant and continuously supplemented, and it deals with consequences of demographic changes on the economy and economic aspects (including the effect on economic growth, productivity and interest rates) as well as social aspects (including the effect on employment hours and types, and social security). Studies on methods to minimise labour force depletion have also been conducted, including supplying labour markets with immigrants, discouraging older employees to benefit from early retirement, increases in birth rate and enhanced professional activity of $60 / 65+$ persons, women and other disadvantaged groups in the labour market. Changes have also occurred in the methodology of studying economic activity, where two new subgroups have been separated from the subset of the professionally passive. In this wide spectrum of analysed issues, certain gaps have been noted in understanding neighbouring labour markets and qualifying particular groups of people as either real or potential labour resources. An understanding of neighbouring labour markets is important for analysing labour resource deficiencies and population migration. Further, a more detailed identification of subsets among the population of unused labour resources and a deeper analysis of professional passiveness determinants may be another method of reducing labour force deficiencies in particular labour markets. An attempt to identify these gaps was the inspiration for undertaking the scientific task of analysing the effect of demographic changes on the labour force volume and redefining the unused labour resource population.

To solve this problem, the research procedure was aimed to answer the following detailed questions:

- What are the trends for changing the population numbers in Lithuania and Poland by 2050?

- Will demographic changes affect the age structure of the population in Lithuania and in Poland?

- What will be the volume of labour force in the context of changes in the total population?

- What labour force group can provide potential labour resources in Lithuania and Poland? 
The problem posed is of a practical nature, as its solution and conclusions drawn can provide inspiration to more accurate decisions to be taken by politicians creating the law in the field of labour market and social policies and by business managers in the field of corporate HR management strategies.

At this point, a question emerges about the reasons for undertaking an analysis of population changes on labour force availability in the above-mentioned countries. The justification is presented below.

- Lithuania and Poland are neighbouring countries and they are both members of the European Union with the four freedoms of the common market: the movement of goods, services, capital and persons. It cannot be ruled out that the last of the above-mentioned freedoms is used to seek "better" jobs by citizens of both countries.

- The existing economic and tourist cooperation already affects labour markets in both countries. Lithuania is the most important commercial partner of Poland among the Baltic States. In 2017, the turnover of both countries was EUR 4.5 billion, which placed Poland in third place among the main business partners of Lithuania, both in terms of export - after Russia and Latvia, and in terms of import after Russia and Germany (Polska Agencja ..., 2018).

- In terms of foreign employees, the labour market in Poland is dominated by workers from Ukraine (according to the estimates of the National bank of Poland - about 1.2 million) and Belarus, but after the change of the regulations on the employment of foreigners in the German market, a quarter of them plan to continue employment in Germany (ManpowerGroup, 2019). The projected situation will increase the labour force shortage in Poland. An increased activity of employers and employment agencies is predicted to increase the search for employees from neighbouring countries, including from Lithuania.

In light of the research problem posed and the justifications provided, the research aimed to evaluate the effect of demographic changes on the labour supply in Lithuania and Poland, and an attempt to redefine groups of people who create unused potential labour resources. Therefore, the demographic changes and labour resources formed the subject of the research based on the population of Lithuania and Poland categorized according to economic age groups. The objective was implemented based on:

- studying research papers concerning the relationship between an increase in population and changes in the labour resources,

- the analysis of the present state (2005, 2010 and 2015) and projected population status by 2050 ,

- own research among 200 respondents qualified for unused potential labour resources,

- the author's proposal to redefine subsets of professionally active and passive people.

In the light of the research objective and the research problems formulated, the following hypothesis was put forward: the projected demographic changes by 2050 will have a negative effect on the labour supply in Lithuania and Poland. The research described in the paper includes both primary and secondary types of studies. The primary research involves a systematic review of the literature and a diagnostic survey conducted among persons classified as the potential labour force, while the secondary research analyses the existing and projected demographic data. The sources of the analysed content included books and research papers as well as statistical reports published mainly by statistical agencies of Lithuania and Poland.

\section{Research Method}

In order to achieve the set goal of the research and verify the hypothesis, an original three-stage algorithm for the research procedure was developed. The first stage included a literature review. The review of research literature was carried out with regard to 1) the impact of demographic changes on labour markets and 2) indications and recommendations as a response to labour shortages. This review aimed to identify, classify and summarize the latest scientific reports, both theoretical and empirical, on the subject of the author's research. The methodology of systematic literature review was applied. To increase the number of reports and international research results in the analyses, a 20-year-long period for a review was adopted. Reports and papers retrieved from electronic databases such as Scopus, Research Gate and Google Scholar (review period from 2000-2019) were considered.

The research procedure at this stage was started with a review of scientific studies placed in the Scopus database. In accordance with the procedure defined in the adopted methodology, a literature search was conducted in three stages using keywords. The first selection of titles and abstracts was the result of searching for the following words: demographic changes, labour market. This led to the identification of 1,296 papers. The second selection was carried out using another keyword: population structure. At this stage, 415 items were identified, and in the third selection - after introducing a keyword: potential labour resources (potential labour force), 90 works were found. After analysing the content of all selected titles and abstracts, 17 items were rejected since the content of these papers was not found to be relevant for the investigated research problem. Thus, 73 papers from the SCOPUS database, including chapters in books, were considered appropriate for further analyses.

The number of research studies selected for a detailed analysis was additionally increased by 26 selected publications from databases, like Research Gate and Google Scholar. These databases were consulted for studies describing policies, strategies, priorities and socioeconomic challenges resulting from the current demographic changes. The studies included in these databases were considered valuable since they were prepared by specialists from such organizations as the European Union (EU), the International Labour Organization (ILO), the Organization for Economic Cooperation and Development (OECD) and financial institutions, i.e. the World Bank, the European Central Bank, the Bank of Australia and the Bank of San Francisco. Since the studies prepared by these institutions are of a practical nature, it is recommended that they should be included in scientific analyses (see e.g. Levy, Ellis, 2006).

The theoretical descriptions and empirical data included in all analysed studies referred either to selected groups of countries, e.g. EU Member States, Balkan countries, OECD 
countries, or to specific countries located in different parts of the world (Canada, China, Egypt, France, Georgia, Germany, Great Britain, Greece, Israel, Italy, Japan, Lithuania, the Netherlands, New Zealand, Niger, Peru, Poland, Romania, Russia, Serbia, Singapore, Slovakia, South Korea, Spain, Sweden, Thailand and the United States).

The research carried out in the second stage was a secondary-type study. In the context of the research subject, various statistical data was compiled to analyse changes in the number and structure of the Lithuanian and Polish populations and the resulting consequences for the labour market, including the potential labour force by 2050 . The data was compiled based on statistical figures presented mainly by Statistics Lithuania, Statistics Poland and Eurostat. The methods applied included descriptive statistics and induction. Selection of data and their analysis were focused on answering the principal research problems and verifying the hypothesis.

The second stage of research was carried out in two ways. First, by using the large volume of knowledge obtained during the first stage of the study, particular population groups who are professionally passive or insufficiently active were classified as unused potential labour resources. Second, a study was conducted among persons with features of the mentioned potential labour force. This study aimed to determine the opinions of people classified into four groups, i.e. unemployed, professionally inactive, pension beneficiaries and partially employed (working part-time or in various non-standard work forms). The research method applied was a diagnostic survey. Interviews with the respondents were carried out using the CATI technique computer-assisted telephone interviewing, with an original interview questionnaire as a research tool. The questionnaire contained 18 questions, including 11 questions concerning the reasons for being out of a professional activity or performing a part-time job, and referring to the conditions that would result in starting work. The remaining seven questions concerned self-evaluation of work ability, according to the Work Ability Index by K. Tuomi (2001).

The survey was conducted with the participation of 50 randomly selected persons from each group of respondents, which makes a total number of 200 conducted interviews. The survey was carried out in the fourth quarter of 2019. This part of the presented results should be treated as a research report since the study was of a pilot type and the respondents were residents of only one region of Poland, i.e. the Warmian-Masurian Voivodeship.

\section{Literature Review}

The literature on the subject for many years has been presenting theoretical deliberations and the results of research concerning demographic changes and resulting economic and social consequences. The research carried out by the International Monetary Fund in 115 countries shows that an increase in GDP per capita is negatively correlated with an increase in the population over 65 years of age (World Economic, 2004). Aksoy et al. (2015) demonstrated that age profile of the population had a statistically significant effect on production increase, investments, savings, hours worked, real interest rates and inflation in the Organisation for Economic Cooperation and Development
(OECD) member countries. On the other hand, Kotowska \& Jozwiak (2012) emphasize that changes in the population age structure have an effect on productivity and economic growth, labour market, social security system and public finances, as well as the demand structure, mainly with regard to care services for elderly people. In turn, Cooley \& Henriksen (2018) indicate that demographic changes will result in a "significant reduction of the economic growth rate, particularly in developed economies". Other researchers (e.g. Backus et al., 2014; Ikeda \& Saito, 2014; Carvalho et al., 2016) demonstrate the effect of demographic changes on capital flows and a decrease in real percentage rates, while other studies found a negative correlation between economic growth and population ageing (Fotakis \& Peschner, 2015).

In the context of the effect exerted by demographic changes, including population ageing, on the economic situation, it should be emphasized that relations between demography and economic growth are very complex and their explanation requires both quantitative evaluation, e.g. analysis of age structure and educational structure of the population, and qualitative evaluation, including an analysis of the level of education and competence of the employees, effects of cultural factors, health conditions, work conditions and principles governing the labour market and economic policy followed in a given country (Bloom \& Canning, 2004; Mester, 2018). The analysis should also take into account the existence of the feedback between changes in the population and economic growth, i.e. that the effect of demographic changes can be economic growth, but this increase can contribute to demographic changes (see e.g. Aksoy et al., 2015).

The present difficulties in the labour market are not caused exclusively by demographic changes. They also result from past short-sighted human resource management (HRM) strategies. Based on the result of research conducted in companies operating in different European countries, two divergent approaches towards the treatment of older workers can be observed. In one approach, older workers are seen as a valuable resource to be looked after. This strategy promotes the employment of older people and extending the active time on the labour market for those employees who are approaching their retirement age (Dalen et al., 2009; Bellmann \& Leber, 2008; Brussig \& Leber, 2019). In contrast, the second approach sees older workers as an unattractive workforce. This approach is unfavourable for older workers, who are often forced into early retirement, and their continued employment, even after the age of 65, is not perceived as one of the possible options for preventing future labour shortages (Guillemar et al., 1996; Chantal et al., 2003; Dalen et. al., 2009).

However, it should be noted that the need to seek solutions in the event of prolonged demographic trends resulting in a shortage of labour resources was identified almost 20 years ago. For instance, P. McDonald \& R. Kippen (2001), researched 16 economically developed countries and demonstrated the need to conduct debates concerning labour supply and international migration. They called for a reversal of the early retirement trend, an increase in women's participation in the labour market, as well as an increase in the birth rate. Other studies have indicated that the stereotypical association of age with a decline in productivity 
and innovation is not always justified as the employee's work and also life experience increases with age. In addition, if older workers participate in training on an ongoing basis, their knowledge and skills increase, which makes them very useful in constantly changing work situations (cf. Sinn, 2003; Akademiegruppe Altern ..., 2009). Other studies also pointed out that one of the ways of counteracting the decline in the labour force will be by increasing labour force participation, especially of older workers, as well as by employing immigrants (Lisenkova et al., 2010).

Decreasing working-age resources and an ageing population compel the search for ways to alleviate labour supply shortages, mainly by extending the employment of people approaching retirement, or by increasing the employment of older workers and skilled migrants. These methods are the subject of studies and publications which suggest remedial actions in the micro- or macro-dimensions. The former includes, among others, offering flexible forms of work, participation in continuing vocational training, encouraging knowledge and skills sharing and cyclical analysis of plans, aspirations and intentions to extend the professional activity of employed workers. On the other hand, the macro dimension suggests the introduction of flexible pension systems and the promotion of public health and the re-orientation of family policies (Luci-Greulich \& Thevenon, 2013; Debroux et al., 2017; Tucas, 2018; Eurostat, 2018). Numerous researchers also emphasize the need to modify migration policies, especially in countries with a negative migration balance (Zimmermann et al., 2007; Kahanec et al., 2009; Pocius \& Gruzevskis, 2019; Oreshkin, 2018; Tukhashvili, 2018; Masi, 2019).

Extending the working life of employed persons and labour market re-entry by retired workers is beneficial to the employee, the employer and the state. Employees benefit since they are not professionally marginalized while working and they stay active while ageing. The advantage for the employer results from the possibility of solving the labour shortage problem and, for the state budget, an improvement of public finances as the employment of pensioners guarantees additional income from wage taxes (Pena-Casas, 2017; Antczak \& Zaidi, 2018; Eurostat, 2018; OECD, 2018). This financial aspect is very important as the population ageing affects increased spending on health and pension funds (Aleksandrova \& Velkova, 2003; Bongaarts, 2004; Lallemand \& Rycx, 2009; Bloom et al., 2010; Botev, 2012). Nevertheless, it should be added that the extension of working life and adaptation of older people in the workplace is determined by their ability to perform work (Tuomi et. al., 2001; Ilmarinen, 2006; Berg et al., 2009). This depends mainly on the physical and social working environment and an individual's health condition (both physical and mental), the level of education and skills and the values and attitudes of older workers (Ilmarinen, 2001; Nilsson et al., 2011).

The positive impact on workers leading to an extension of their working life requires knowledge of the reasons for early retirement or for not applying for an extension of work beyond the statutory retirement age. The literature on the subject most frequently refers to:

- age discrimination, myths and stereotypes concerning the productivity of older employees (Ilmarinen, 2001);

- decreased motivation, resulting, among others, from not participating in training (Kanfer \& Ackerman, 2004; Damman et al., 2011);

- the need for a better balance between personal and professional life (Geuskens et al., 2012);

- high work pressure and low job satisfaction (Berg et al., 2010);

- health constraints and disorders (Ilmarinen, 2006; Berg et al., 2010).

Summarizing the conducted literature review, it can be stated that the impact of demographic changes on the size and structure of the population has been the subject of multifaceted research for many years. However, there is a scarcity of scientific studies and joint analyses concerning the Lithuanian and Polish labour markets, as well as a lack of recommendations based mainly on the empirical material. In this context, the research undertaken is new and enriches the literature on the subject.

\section{Results and Discussion}

Demographic changes are also reflected in the labour market, which consequently entails not only economic, but also various social problems, which are already occurring and will intensify over the years. The situation in the labour market can be analysed in various aspects, e.g. in the context of labour market participation of the population, "entering" the labour market and the migration of the population. The values of factors defining labour market participation of the population concerning people aged 15-64 are more favourable in Lithuania (75.9\%) than in Poland (69.6\%), compared with the EU average of $73.3 \%$ (Tab. 1).

Table 1

Employment Rates of Persons Aged 20-64 in Lithuania and Poland (in \%)

\begin{tabular}{|l|c|c|c|c|c|c|c|c|c|}
\hline \multicolumn{1}{|c|}{ Specification } & $\mathbf{2 0 1 0}$ & $\mathbf{2 0 1 1}$ & $\mathbf{2 0 1 2}$ & $\mathbf{2 0 1 3}$ & $\mathbf{2 0 1 4}$ & $\mathbf{2 0 1 5}$ & $\mathbf{2 0 1 6}$ & $\mathbf{2 0 1 7}$ & Assumed objective \\
\hline Lithuania & 64.3 & 66.9 & 68.5 & 69.9 & 71.8 & 73.3 & 75.2 & 76.0 & 72.8 \\
\hline Poland & 64.3 & 64.5 & 64.7 & 64.9 & 66.5 & 67.8 & 69.3 & 70.9 & 71.0 \\
\hline
\end{tabular}

Source: Eurostat. (2018). Underemployment and potential additional labour force statistics http://ec.europa.eu/eurostat/web/europe-2020-indicators/europe-2020-strategy/main-tables

Another variable which affects the situation in the labour market is the average age of persons starting their jobs. As results from the data of Eurostat, young Lithuanians and Poles holding higher education diplomas enter the labour market at a similar age (24.3 and 24.9 years, respectively). The amount of future labour resources also depends on the migration rate; both internal and external (see Gruzevskis, 2018, i.a.).
Unfortunately, in both countries under analysis, the migration rate is negative, which means that more people emigrate than immigrate, thus deepening the unfavourable situation in their labour markets (Eurostat, 2015). Data on the European Migration Network (Europos migracijos tinklas, 2016) show that almost $72 \%$ of emigrants from Lithuania are aged 1544 , while a potential emigrant from Poland is between 18 and 
34 years old (45\%) (Migracje zarobkowe Polakow, 2018). In the first and the second case, these persons are the most useful for the economy, as they are in the economic production age group. Pocius and Okuneviciute Neverauskiene (2017) dealt with the diversity of regional labour market indicators in Lithuania in the context of demographic changes. The authors observed the occurrence of more unfavourable changes in less attractive labour markets (economically poorer regions, smaller localities), which result, among others, from interregional workforce flows. These processes result in an even more severe shortage of labour resources in these areas, and, in consequence, increase the socio-economic differences between individual regions.

As previously mentioned, demographic changes also affect the social situation in individual countries, which pose new challenges as regards cooperation between generations. Those challenges are articulated in documents issued by various institutions and by numerous authors. For instance, the documents of the European Commission include contentpromoting solidarity between generations (European UnionCOM, 2005). In the context of the above-mentioned solidarity between generations, age dependency ratios, describing the level of support granted by the population at working age (aged 15-64) to younger (0-14 years old) or older persons (aged 65 and more) should also be mentioned. Combining the child dependency ratio with the old-age dependency ratio provides the total dependency ratio. The values of these ratios for Lithuania and Poland are similar (Tab. 2).

Table 2

Dependency Ratios (\%)

\begin{tabular}{|l|c|c|c|}
\hline Specification & $\begin{array}{c}\text { Child } \\
\text { dependency } \\
\text { ratio }\end{array}$ & $\begin{array}{c}\text { Old-age } \\
\text { dependency } \\
\text { ratio }\end{array}$ & $\begin{array}{c}\text { Total } \\
\text { dependency } \\
\text { ratio }\end{array}$ \\
\hline Lithuania & 22.5 & 29.3 & 51.8 \\
\hline Poland & 22.1 & 24.2 & 46.3 \\
\hline
\end{tabular}

Source: Eurostat (2017). Population Age Structure Indicators; http://appsso.eurostat.ec.europa.eu/nui/show.do?dataset=demopja nind
The literature on the subject, apart from describing dependencies between population changes and changes in economic development, includes analyses of the causes and negative consequences of population ageing. The major causes include a low birth rate and gradually increasing average life expectancy. Birth rate, also referred to as the fertility rate, is expressed by the total fertility rate (TFR). Its values provide information about the so-called simple replacement of generations. For this replacement to occur, TFR should not be lower than 2.1-2.15. Unfortunately, the fertility rates recorded for several years in European countries have been low (with TFR amounting to 1.35-1.5) or very low (not higher than 1.35) (Kotowska, 2014). Lithuania and Poland have also experienced this trend. In 1990, the TFR in Lithuania was 1.99, and in Poland it was 2.06 , but in 2012 the values were 1.6 and 1.3 , respectively (Glowny Urzad Statystyczny, 2014).

Changes in the population size and structure help to make the most accurate decisions in economic and social areas. These issues are analysed in such aspects as a change in the general number of people, changes by sex and place of residence, generation replacement ability, or population structure by economic age. Each of these aspects is important and provides different information. The research presented in this paper focuses on the effect of demographic changes on the amount of the potential labour force.

Both countries under analysis have been experiencing a decrease in population for several years. In Lithuania, the decrease started in 1991, from the status of $3,704,100$ people, and in Poland in 1999, from the status of 38,660,300 people. Decreasing trends are continued today, and according to demographers, they will last for the next few decades. Figure 1 presents the projected population of Lithuania and Poland by 2050.

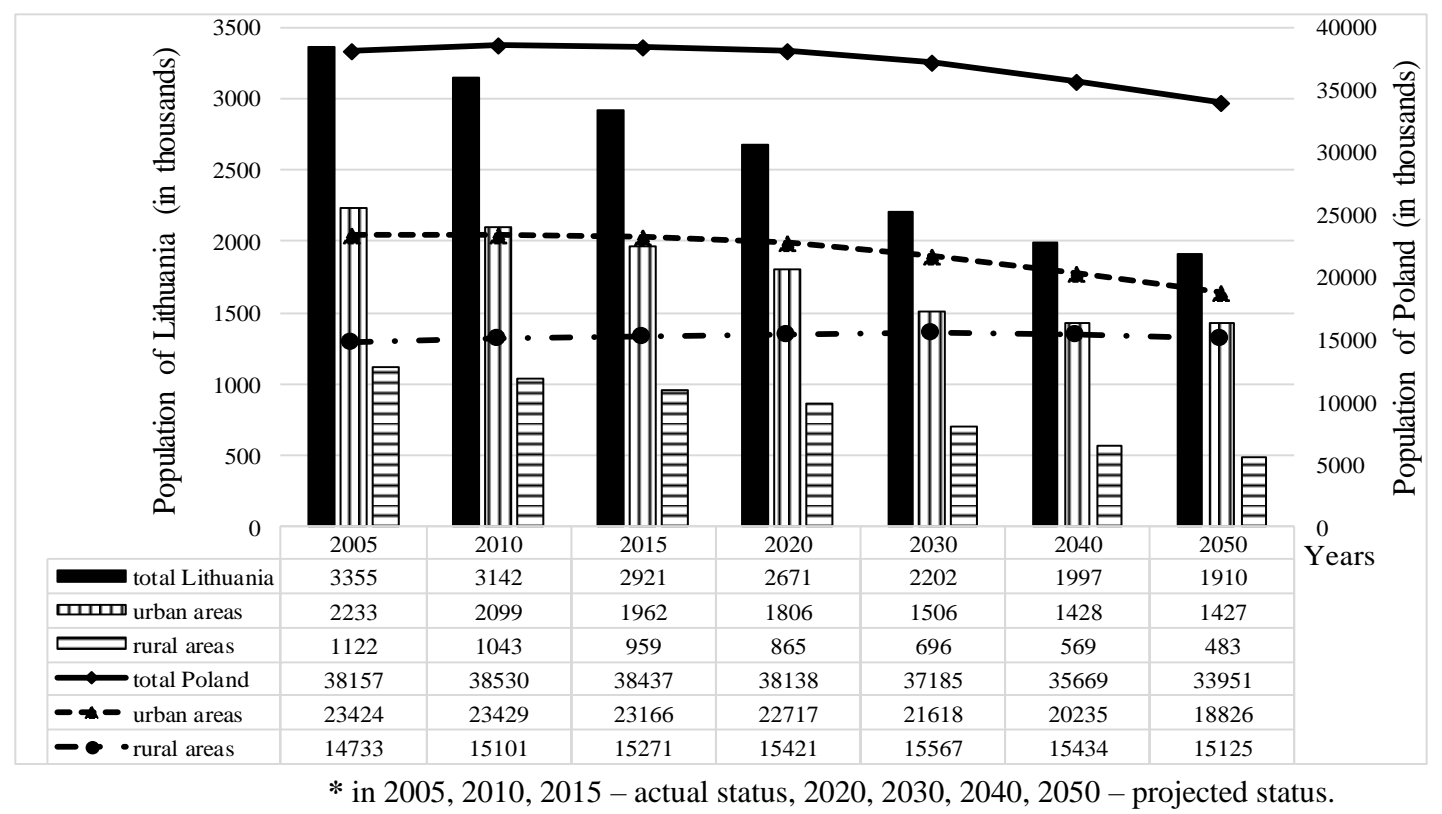

Figure 1. Population of Lithuania and Poland in 2005-2050 (in thousands of people) Source: Own Study Based on Demografijos metrastis 2014, 2016; Rocznik Statystyczny RP 2014, 2018 
Comparing population numbers from the initial and the final year of the analysis, one can observe a decrease in the total population in both urban and rural areas in Lithuania, while in Poland a decrease in the total population results from a decrease in population in urban areas. On the other hand, the population in Polish rural areas is increasing (except 2050), but this increase does not cover shortages in urban areas. The percentage structure of the population of Lithuania and Poland by the place of residence is presented in Table 3.

Table 3

Percentage Structure of the Population in Lithuania and Poland by the Place of Residence in 2005-2050 (\%)

\begin{tabular}{|l|l|c|c|c|c|c|c|c|}
\hline \multicolumn{2}{|c|}{ Specification } & $\mathbf{2 0 0 5}$ & $\mathbf{2 0 1 0}$ & $\mathbf{2 0 1 5}$ & $\mathbf{2 0 2 0}$ & $\mathbf{2 0 3 0}$ & $\mathbf{2 0 4 0}$ & $\mathbf{2 0 5 0}$ \\
\hline \multirow{3}{*}{ Lithuania } & total & 100.0 & 100.0 & 100.0 & 100.0 & 100.0 & 100.0 & 100.0 \\
\cline { 2 - 10 } & urban areas & 66.6 & 66.8 & 67.2 & 67.6 & 68.4 & 71.5 & 74.7 \\
\cline { 2 - 10 } & rural areas & 33.4 & 33.2 & 32.8 & 32.4 & 31.6 & 28.5 & 25.3 \\
\hline \multirow{3}{*}{ Poland } & total & 100.0 & 100.0 & 100.0 & 100.0 & 100.0 & 100.0 & 100.0 \\
\cline { 2 - 9 } & urban areas & 61.4 & 60.8 & 60.3 & 59.6 & 58.1 & 56.7 & 55.5 \\
\cline { 2 - 9 } & rural areas & 38.6 & 39.2 & 39.7 & 40.4 & 41.9 & 43.3 & 44.5 \\
\hline
\end{tabular}

Source: Own Study Based on Demografijos Metrastis 2014, 2016; Rocznik Statystyczny RP 2014, 2018.

As results from the percentage structure of the population, with decreasing total population, the percentage of urban dwellers in Lithuania is increasing, which may result, among others, from the movement of rural population to urban areas which offer better opportunities (jobs, flats) (Pocius \& Okuneviciute Neverauskiene, 2017). In Poland, in turn, the decrease in the urban population is caused by external emigration, as well as by internal emigration (a trend has been observed for years to change the place of residence by moving from urban to rural areas while holding a job in the city).
Unfavourable changes in the number of inhabitants of Lithuania and Poland result, among others, from low birth rate values (Fig. 2). The consequence of this state is (and will continue to be) the absence of a simple replacement of generations. However, according to demographers, by 2050 the value of the rate under analysis will gradually increase, yet it will have no impact on the potential labour resources in the analysed period. This conclusion results from the current educational systems in Lithuania and Poland, as children born now and in the upcoming years will still be learning, therefore by 2050 , they will still be in the preworking age subset.

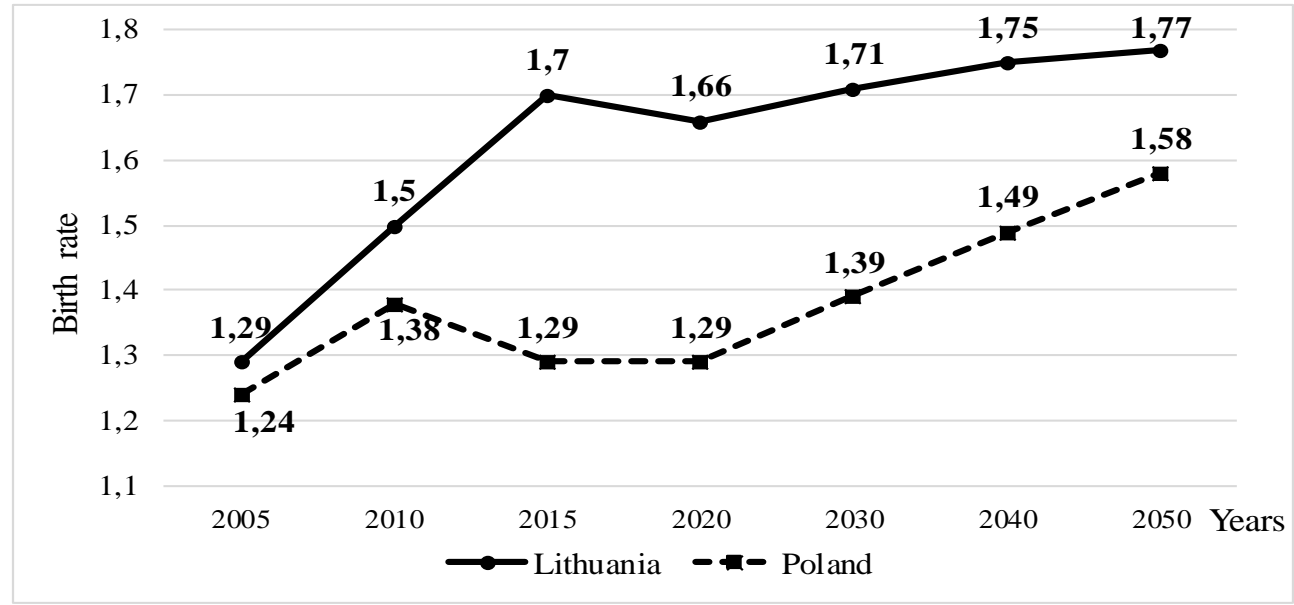

Figure 2. Projected Birth Rate in Lithuania and Poland by 2050

Source: Own Study Based on Demografijos Metrastis 2014, 2018; Rocznik Statystyczny RP 2014, 2018

Along with demographic changes, the population structure classified according to the economic age, i.e. preworking age (persons aged $0-14$ years), working-age (15-
$64)$ and post-working age (65 and more) is changing. Figure 3 presents the changes in the number of population by age groups and Table 4 shows their percentage structure. 


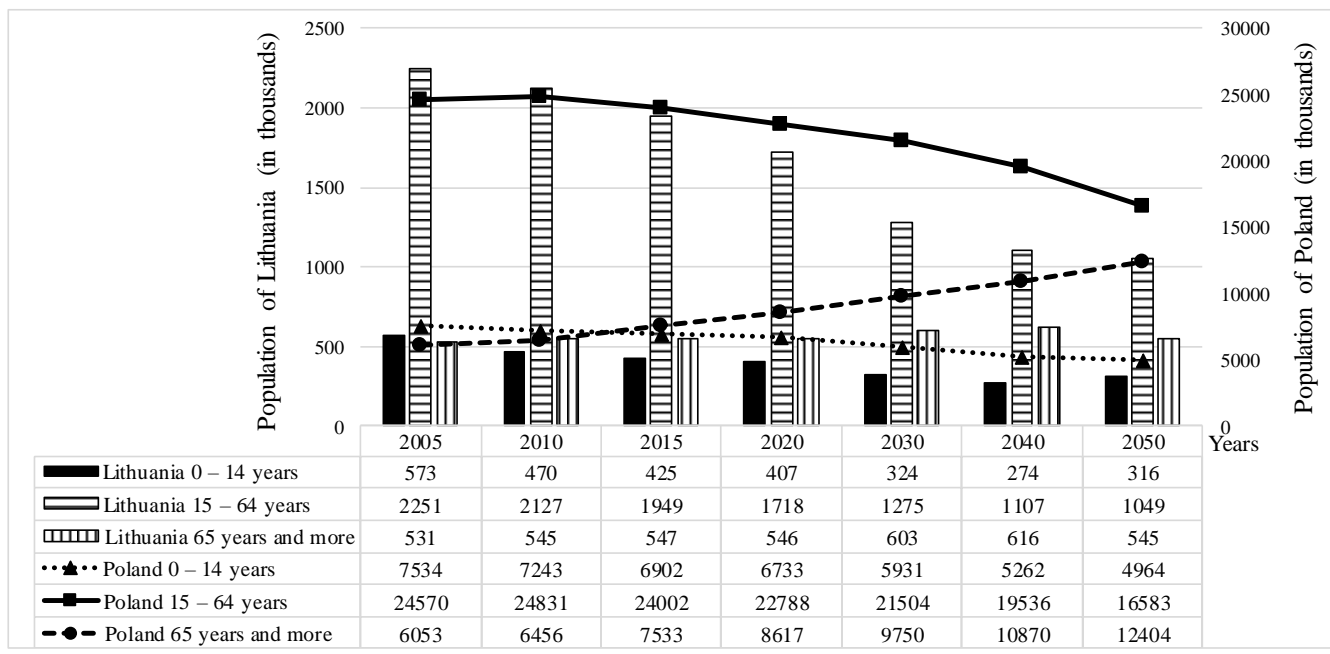

Figure 3. Population of Lithuania and Poland by Economic Age (in thousands of people)

Source: Own Study Based on Demografijos metrastis 2014, 2016; Rocznik Statystyczny RP 2014, 2018

Percentage Structure of the Population in Lithuania and Poland by Economic age in 2005-2050 (\%)

\begin{tabular}{|c|l|c|c|c|c|c|c|c|}
\hline \multicolumn{2}{|c|}{ Specification } & $\mathbf{2 0 0 5}$ & $\mathbf{2 0 1 0}$ & $\mathbf{2 0 1 5}$ & $\mathbf{2 0 2 0}$ & $\mathbf{2 0 3 0}$ & $\mathbf{2 0 4 0}$ & $\mathbf{2 0 5 0}$ \\
\hline \multirow{4}{*}{ Lithuania } & $0-14$ years & 17.1 & 15.0 & 14.6 & 15.3 & 14.7 & 13.7 & 16.6 \\
\cline { 2 - 9 } & $15-64$ years & 67.1 & 67.7 & 66.7 & 64.3 & 57.9 & 55.4 & 54.9 \\
\cline { 2 - 9 } & $\begin{array}{l}\text { 65 years and } \\
\text { more }\end{array}$ & 15.8 & 17.3 & 18.7 & 20.4 & 27.4 & 30.9 & 28.5 \\
\hline \multirow{3}{*}{ Poland } & $0-14$ years & 19.7 & 18.8 & 18.0 & 17.6 & 15.9 & 14.7 & 14.7 \\
\cline { 2 - 9 } & $15-64$ years & 64.4 & 64.4 & 62.4 & 60.0 & 57.9 & 54.8 & 48.8 \\
\cline { 2 - 9 } & 65 and more & 15.9 & 16.8 & 19.6 & 22.4 & 26.2 & 30.5 & 36.5 \\
\hline
\end{tabular}

Source: Own Study Based on Demografijos Metrastis 2014, 2016; Rocznik Statystyczny RP 2014, 2018

The values presented in the figure and the table show a consistent decrease in the population at pre-working and working ages in both countries, with a simultaneous increase in the number of persons at post-working age. Around 2050, positive changes can be expected in Lithuania in the number of the youngest persons. At the same time, it is observed that unfavourable changes are more pronounced in Poland than in Lithuania. From a comparison of the population status in 2050 with the data recorded for 2005 , similar values are obtained as regards a decrease in the number of people of production age in Lithuania and Poland (-12.2 and -15.6 percentage points, respectively). However, there are significant differences regarding the changes in pre-working age population $(-0.5$ and -5.0 percentage points, respectively) and working-age $(+12.7$ and +30.6 percentage points, respectively). The analysed results prove that there is a shortage of people of production age, with a simultaneous significant increase in the number of elderly persons in both countries.

In view of the above-mentioned unexploited changes in the labour markets in Lithuania and Poland in the years ahead (until 2050), it is essential to strive for more optimal use of real and potential labour resources. According to the definitions of the International Labour Organization and national statistical offices adopted in the studies on labour participation (Labour Force Survey), the population aged 15-74 is classified as employed persons, unemployed persons and economically inactive persons. The subset of employed persons includes full-time employees and a separate group of employees working on a part-time basis in relation to the statutory time (i.e. visible part-time employment). All employed and unemployed are economically active persons. On the other hand, the subset of economically inactive persons was divided into inactive persons searching for employment but unready to accept employment, inactive persons not searching for employment, but ready to take it, and other inactive persons. The two first groups of economically inactive persons gather people at the edge of unemployment and economic inactivity, but it can be assumed that there exists a high chance to introduce them to the labour market. Therefore, they are referred to as potential labour resources (potential labour force). In turn, the sum of part-time employed, unemployed and potential resources creates a set of unused potential labour resources (De la Fuente, 2011; Mecina, 2013).

Based the referred interpretations, it seems justified to expand the population groups of unused potential labour (Figure 4). It has been proposed to introduce two new groups to the subsets of both the working population and the professionally passive population. A new subset of the working population would include those employed in nonstandard employment forms who work fewer hours than the statutory full-time employment, although they would like to work longer hours. This working time difference constitutes the unused productivity of the persons employed in nonstandard employment forms. 


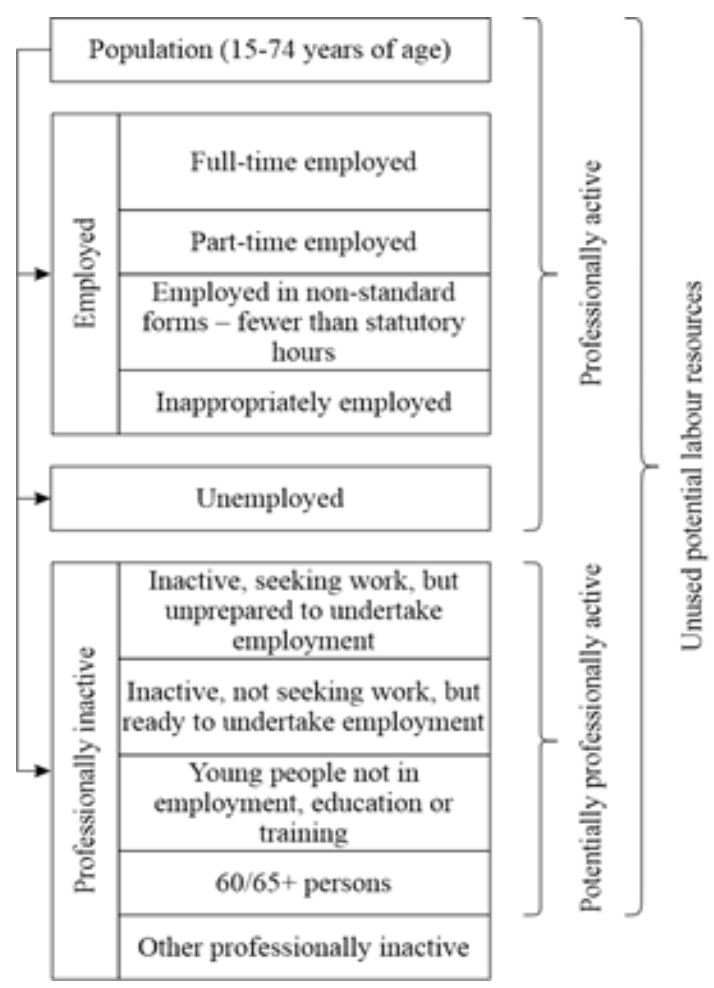

Figure 4. Structure of Unused Potential Labour Resources Source: own study

On the other hand, the second group in the subset of the employed would be people who were under-employed, as problems of incomplete utilization of production capacity concern not only part-time employees, but also full-time employees. In practice, there are situations of competence mismatches, which result in inadequate use of knowledge, skills, experience and personal predispositions of employees. Inappropriate employment also exists when remuneration of employees is not in line with the difficulties and results of their work and in situations of excessively long hours of work, which can also be interpreted as excessive employment (see e.g. Vandenbroek, 2018).

The category of inappropriate employment also includes excessive employment. It is a certain paradox that the above-mentioned situations related to employment on a full-time basis (and even over the legally established working hours and to excessive employment) can be included in the so-called invisible under-employment. This classification is justified, since such inappropriate employment leads to de-motivation of the employee, resulting in lower productivity. Moreover, the two new groups in the professionally passive subset would constitute persons disadvantaged in the labour market, i.e. young people not in employment, education or training (NEET) and the 60/65+ persons (women/men respectively).

In light of the above explanations, it seems necessary to undertake measures aimed at increasing the economic activity of persons included in the group of unused potential labour resources. These measures may be more effective if the reasons for completely passive or limited labour market activity of people who are classified as unused labour resources are known. Table 5 presents the most significant responses provided by the unemployed, professionally inactive, retired and employed "temporarily", e.g. for a fixed period, concerning their activity in the labour market.

Table 5

Selected Responses of Persons Classified as Unused Labour Resources

\begin{tabular}{|c|c|c|c|c|}
\hline Answers provided by respondents & Unemployed & $\begin{array}{l}\text { Professionally } \\
\text { inactive }\end{array}$ & Retired & "Partially" employed \\
\hline \multicolumn{5}{|c|}{ Question: What circumstances would be conducive to taking up employment? (\%) } \\
\hline Flexible working hours & 46.3 & 40.1 & 21.6 & $\mathrm{X}$ \\
\hline Possibility of doing some work from home & 24.0 & 30.0 & 42.4 & $\mathrm{x}$ \\
\hline Part-time employment & 26.1 & 16.2 & 38.9 & $\mathrm{X}$ \\
\hline \multicolumn{5}{|c|}{ Question: What are the main reasons preventing people aged $60+/ 65+$ from continued work? $(\%)$} \\
\hline Deteriorating physical condition & $\mathrm{X}$ & $\mathrm{x}$ & 48.0 & $\mathrm{X}$ \\
\hline $\begin{array}{l}\text { Workplaces not adjusted for the needs of older } \\
\text { employees }\end{array}$ & $\mathrm{X}$ & $\mathrm{X}$ & 44.2 & $\mathrm{X}$ \\
\hline Not very positive perception by younger workers & $\mathrm{x}$ & $\mathrm{x}$ & 40.2 & $\mathrm{X}$ \\
\hline \multicolumn{5}{|c|}{ Question: Why do you work part-time? (\%) } \\
\hline No full-time work in the immediate vicinity & $\mathrm{x}$ & $\mathrm{x}$ & $\mathrm{X}$ & 44.4 \\
\hline $\begin{array}{l}\text { Difficulties in combining family responsibilities with } \\
\text { professional work }\end{array}$ & $\mathrm{x}$ & $\mathrm{x}$ & $\mathrm{x}$ & 28.3 \\
\hline A desire to receive additional remuneration & $\mathrm{x}$ & $\mathrm{X}$ & $\mathrm{X}$ & 20.3 \\
\hline \multicolumn{5}{|c|}{ Question: Are you interested in full-time and permanent employment? $(\%)$} \\
\hline Total answers: Yes and Definitely yes & 22.6 & 20.4 & 10.3 & 44.1 \\
\hline Total answers: No and Definitely not & 12.1 & 21.3 & 63.7 & 29.9 \\
\hline I did not think about that & 65.3 & 58.3 & 26.0 & 34.0 \\
\hline \multicolumn{5}{|c|}{ Self-assessment of work ability (score) } \\
\hline Result according to Work Ability Index & 28 & 25 & 24 & 25 \\
\hline
\end{tabular}

$\mathrm{x}$ - The question was not addressed to this group of respondents Source: Own Research

The results shown in the table demonstrate that the most attractive form of employment for the unemployed and professionally inactive persons would be taking up employment with flexible working hours. In contrast, retired people would be most comfortable when working from home or as part-time employees since only one in ten of 
them is interested in full-time employment. As regards the employment of this group of potential labour resources, what is alarming is that the main reasons for their reluctance to look for and take up work are low-quality jobs for older people and not very friendly relations with younger employees. Respondents without a permanent job declared that the reason for such a situation is the lack of full-time job offers in their area of residence. At the same time, only slightly more than $40 \%$ of them expressed their willingness to undertake permanent full-time work. The results of the respondents' self-assessment concerning their ability to work were low. The unemployed evaluated it as average, while respondents from other groups evaluated it as poor.

\section{Conclusions}

This study aimed to evaluate the effect of demographic changes on the labour supply in Lithuania and Poland and to identify possible remedial actions to mitigate labour shortages. This aim was achieved through the systematic review of the literature on the subject and the analysis of changes in the population age structure. The adopted research methodology and procedure provided answers to the posed questions and enabled a positive verification of the study hypothesis.

The undertaken review and the interpretation of the results from original research, as well as own reflections, point to the need for a broader interpretation of one of the labour resource components, i.e. the subset of persons employed on a part-time basis. The subset of those resources include people employed on a part-time basis (e.g. working for a half of the statutory working hours, weekend workers) and people inappropriately employed, i.e. not in line with their competences (excess or shortage of skills as compared to the job description), as well as over-employed persons, i.e. not in line with labour demand. The analysis made allows more accurate estimation of unused potential labour resources.

The results of own research concerning the opinions of people classified as unused labour force can be approached in two ways. On the one hand, it provides a positive image, because it is optimistic to discover that people who are considered as unused labour force want to take up employment. On the other hand, only a few of them would like to have permanent and full-time employment, which is

Proofreading by: Mark Jensen a negative image. The respondents' self-assessment concerning their ability to work was also unsatisfactory. To analyse the reasons for such a state of affairs in more detail, it would be necessary to identify, among others, the duration of unemployment or professional inactivity, as practice shows that the longer the duration of professional inactivity, the more difficult it is to return to the labour market.

People classified as a potential labour force do not form a homogeneous group and, therefore, their numerous and various needs and ambitions, identified in cyclical quantitative and qualitative research, should be taken into account in human resources policies in enterprises and regions (micro dimension) and public policies (macro dimension). In this context, it is necessary to include age management measures in the human resources strategy, expressed in offering flexible forms of employment to older workers, participation in vocational training, extra days of holiday leave, availability of additional medical care and the introduction of tax incentives and other employee benefits.

Another way to overcome the shortage of labour resources may be to increase the economic activity of specific groups of the workforce, in particular:

- women bringing up children, by offering them flexible forms of work, reducing tax burdens and increasing the availability of childcare institutions (crèches, kindergartens), as well as the elimination of discrimination in terms of remuneration and professional functions/roles;

- disabled persons, through the elimination of architectural barriers in all areas of life (housing, educational, work and road infrastructure), increasing the number of jobs in sheltered workshops, employment under non-standard work arrangements and elimination of discrimination against job candidates based on disability.

The content presented in the paper has certain limitations resulting from the review of the scientific literature from only three databases, as well as from the nonrepresentative group of respondents representing potential labour resources. Although the analysis presented in the paper addresses only a fragment of this multifaceted and complex problem, the current study is a modest contribution to filling the gap in the area under analysis and encourages further research into effective management of the most valued assets, i.e. already working and potential employees.

\section{References}

Akademiegruppe Altern in Deutschland. Gewonnene Jahre. Stuttgart, Wissen-schaftliche Verlagsgesellschaft, Band 9/2009. Available from internet: https://www.socialnet.de/rezensionen/7946.php.

Aksoy, Y., Basso, H. S., Smith, R. P., \& Grasl, T. (2015). Demographic Structure and Macroeconomic Trends. Working Paper, 1528, 1-68. Banco de Espana, Madrid. Available from internet: https://www.bde.es/f/webbde/SES/Secciones/ Publicaciones/PublicacionesSeriadas/DocumentosTrabajo/pdf. https://doi.org/10.2139/ssrn.2669321

Aleksandrova, S., \& Velkova, A. (2003). Population ageing in the Balkan countries. Folia Medica (Plovdiv), 45(4), 5-10. Available from internet: https://www.ncbi.nlm.nih.gov/pubmed/15272808.

Antczak, R., \& Zaidi, A. (2018). Well-Being of Older Persons in Central and Eastern European Countries. Research on Ageing and Social Policy, 6(1), 26-52. Available from internet: https://www.researchgate.net/publication/326036304 _Wellbeing_of_older_persons_in_Central_and_Eastern_European_countries. https://doi.org/10.17583/rasp.2018.3109 
Backus, D., Cooley, T., \& Henriksen, E. (2014). Demography and low-frequency capital flows. Journal of International Economics, INEC 2749, 1-9. Available from internet: http://pages.stern.nyu.edu/ dbackus/BCH/ms/Proofs _INEC_2749.pdf.

Bellmann, L., \& Leber, U. (2008). Weiterbildung fur Altere in KMU. Sozialer Fortschritt, 57(2), pp. 43-48. Available from internet: https://elibrary.duncker-humblot.com/journals/id/21/vol/57/iss/1216/art/4019. https://doi.org/10.3790/ sfo.57.2.43

Berg, Van den, T. I., Elders, L. A., Zwart, de, B. C., \& Burdorf, A. (2009). The effects of work-related and individual factors on the Work Ability Index: a systematic review'. Journal of Occupational and Environmental Medicine, 66(4), pp. 211-220. Available from internet: https://www.ncbi.nlm.nih.gov/pubmed/19017690. https://doi.org/10.1136/oem.20 $\underline{08.039883}$

Berg, Van den, T. I., Elders, L. A., \& Burdorf, A. (2010). Influence of Health and Work on Early Retirement'. Journal of Occupational and Environmental Medicine, 52(6), pp. 576-583. Available from internet: https://www.researchgate.net/publication/44649244_Influence_of_Health_and_Work_on_Early_Retirement. https://doi.org/10.1097/JOM.0b013e3181de8133

Bloom, D. E., \& Canning, D. (2004). Global demographic change: Dimensions and economic significance. NBER Working Paper, 10817, 1-45. Available from internet: http://www.nber.org/papers/w10817. https://doi.org/10.3386/w10817

Bloom, D. E., Canning, D., \& Fink, G. (2010). Implications of Population Ageing for Economic Growth. Oxford Review of Economic Policy, 26(4), 583-612. https://doi.org/10.1093/oxrep/grq038

Bongaarts, J. (2004). Population Aging and the Rising Cost of Public Pensions. Population and Development Review, 30(1), 1-23. Available from internet: https://www.popcouncil.org/uploads/pdfs/councilarticles/pdr/PDR301Bongaarts.pdf. https://doi.org/10.1111/j.1728-4457.2004.00001.x

Botev, N. (2012). Population ageing in Central and Eastern Europe and its Demographic and Social Context. European Journal of Ageing, 9(1), 69-79. https://doi.org/10.1111/j.1728-4457.2004.00001.x

Brussig, M., \& Leber, U. (2019). After early retirement: the variety of human-resource strategies of firms towards older employees. Journal for Labour Market Research, 53(15), 1-13. https://doi.org/10.1186/s12651-019-0266-Z

Carvalho, C., Ferrero, A. \& Nechio, F. (2016). Demographics and Real Interest Rates: Inspecting the Mechanism. Working Paper, 05, 1-31. Federal Reserve Bank of San Francisco. Available from internet: http://www.frbsf.org/economicresearch/publications/working-papers/wp2016-05.pdf.

Chantal, R., Henkens, K., Schippers, J., \& Ekamper (2003). Managing an Aging Workforce and a Tight Labor Market: Views held by Dutch employers. Population Research and Policy Review, No 22, pp. 21-40. Available from internet: https://www.researchgate.net/publication/236682098_Managing_an_Aging_Workforce_and_a_Tight_Labor_Marke t_Views_Held_by_Dutch_Employers.

Cooley, T., \& Henriksen, R. (2018). Balansowanie miedzy skutkami zmian demograficznych. Obserwator Finansowy VoxEu, Available from internet: https://www.obserwatorfinansowy.pl/forma/rotator/balansowanie-miedzy-skutkamizmian-demograficznych.

Dalen, V., Hendrik, P., Henkens, K., \& Schippers, J. (2009). Dealing with older workers in Europe: a comparative survey of employers' attitudes and actions. Journal of European Social Policy, 19(1), 47-60. Available from internet: https://doi.org/10.1177/0958928708098523

Damman, M., Henkens, K., \& Kalmijn, M. (2011). The Impact of Midlife Educational, Work, Health, and Family Experiences on Men's Early Retirement. Journals of Gerontology-Series B Psychological Sciences and Social Sciences, 66(5), 617-627. Available from internet: https://academic.oup.com/psychsocgerontology/article/66B/5/ 617/543527. https://doi.org/10.1093/geronb/gbr092

Debroux, P., Jaussaud, J., \& Martine, J. (2017). Elderly workers in Japan the need for a new approach. Transition Studies Review, 24(2), 31-43. Available from internet: https://doi.org/10.14665/1614-4007-24-2-004.

De la Fuente, A. (2011). New measures of labour market attachment. 3 new Eurostat indicators to supplement the unemployment rate. Statistics in Focus, 57, 1-8. Eurostat, European Union, Luxembourg. Available from internet: https://ec.europa.eu/eurostat/documents/3433488/5579744/KS-SF-11-057-EN.PDF.

Demografijos metrastis 2014. (2015). Lietuvos statistikos departamentas, Vilnius. Available from internet: https://osp.stat.gov.lt/services-portlet/pub-edition-file?id=19938.

Demografijos metrastis 2016. (2017). Lietuvos statistikos departamentas, Vilnius. Available from internet: https://osp.stat.gov.lt/services-portlet/pub-edition-file?id=27100.

Demografijos metrastis 2018. (2019). Lietuvos statistikos departamentas, Vilnius. Available from internet: https://osp.stat.gov.lt/services-portlet/pub-edition-file?id=19938. 
European Commission. (2005). Green Paper: Confronting Demographic Change: a New Solidarity between the Generations. Communication from the Commission, Brussels, COM (2005), 94 final. Available from internet: http://ec.europa.eu/transparency/regdoc/rep/1/2005/EN/1-2005-94-EN-F1-1.pdf.

Europos migracijos tinklas. Migracija skaiciais. (2016). Available from internet: http://123.emn.lt/.

Eurostat. (2015). Demography for All. Available from internet: https://ec.europa.eu/eurostat/data/database?node_ code $=$ proj.

Eurostat. (2016). Underemployment and potential additional labour force statistics. Available from internet: http://ec.europa.eu/eurostat/statistics-explained/index.php.

Eurostat. (2017). Population age structure indicators. Available from internet: http://appsso.eurostat.ec.europa.eu/nui/ show.do?dataset=demo_pjanind.

Eurostat. (2018). Employment \& Active participation. AGE Platform Europe; https://www.age-platform.eu/policywork/employment-active-participation.

Fotakis, C., \& Peschner, J. (2015). Demographic change, human resources constraints and economic growth. The EU challenge compared to other global players. Working Paper, 1, 1-68. European Union. Available from internet: http://ec.europa.eu/social/main.jsp?catId=113\&langId=en.

Geuskens, G. A., Oude Hengel, K. M., Koppes, L. L. J., \& Ybema, J. F. (2012). Predictors of the willingness and ability to continue working until the age of 65 years. Journal of Occupational and Environmental Medicine, 54, 572-578. https://doi.org/10.1097/JOM.0b013e318248057a

Glowny Urzad Statystyczny. (2014). Prognoza ludności na lata 2014-2050. Warszawa.

Gruzevskis, B. (2018). Darbo rinkos perspektyvos demografinių pokycių kontekste. Lietuvos demografijos forumas. Vilnius. Available from internet: https://epilietis.lrv.1t/.../Boguslavas\%20Gruzevskis_\%202018_Dem.

Guillemar, A., Taylor, P., \& Walker, A. (1996). Managing an Ageing Workforce in Britain and France. The Geneva Papers on Risk and Insurance, 21, 478-501. https://doi.org/10.1057/gpp.1996.32

Ikeda, D., \& Saito, M. (2014). The effects of demographic changes on the real interest rate in Japan. Japan and the World Economy, 32, 37-48 Available from internet: https://econpapers.repec.org/article/eeejapwor/v_3a32_3ay_3a2014_ 3ai_3ac_3ap_3a37-48.htm. https://doi.org/10.1016/j.japwor.2014.07.005

Ilmarinen, J. E. (2001). Aging workers. Occupational and Environmental Medicine, 58, 546-552. Available from internet: https://oem.bmj.com/content/58/8/546. https://doi.org/10.1136/oem.58.8.546

Ilmarinen, J. (2006). The ageing workforce - challenges for occupational health'. Occupational Medicine, 56(6), $362-364$. https://doi.org/10.1093/occmed/kq1046

Kahanec, M., Zaiceva, A., \& Zimmermann, K. F. (2009). Lessons from Migration after EU Enlargement. Discussion Paper, No. 4230, 1-42. IZA - Forschungsinstitut zur Zukunft der ArbeitInstitute for the Study of Labor, Bon. https://doi.org/10.1007/978-3-642-02242-5_1

Kanfer, R., \& Ackerman, P. L. (2004). Aging, Adult Development and Work Motivation. Academy of Management Review, 29(3), 440-458. Available from internet: https://www.researchgate.net/publication/242542558_Aging_Adult_ Development_and_Work_Motivation.https://doi.org/10.5465/amr.2004.13670969

Kotowska, I. E., \& Jozwiak, I. (2012). Nowa demografia Europy a rodzina. Roczniki Kolegium Analiz Ekonomicznych Szkoly Glownej Handlowej, 28, 9-33. Available from internet: http://rocznikikae.sgh.waw.pl/p/roczniki _kae_z28_01.pdf.

Kotowska, I. E. (2014). Mastering Demographic Change in Europe - wspolne stanowisko osmiu europejskich akademii nauk. Nauka, 4, 21-27. Available from internet: http://journals.pan.pl/dlibra/publication/106491/edition/92259 /content/mastering-demographic-change-in-europe.

Lallemand, T., \& Rycx, F. (2009). Are Older Workers Harmful for Firm Productivity? Economist, 157(3), $273-292$. Available from internet: https://www.researchgate.net/publication/225120399_Are_Older_Workers_Harmful_for_ Firm_Productivity. https://doi.org/10.1007/s10645-009-9126-5

Levy, Y., \& Ellis, T. J. (2006). A Systems Approach to Conduct an Effective Literature Review in Support of Information Systems Research. Informing Science, 9, 181-212. Available from internet: http://www.inform.nu/Articles/Vol9/ V9p181-212Levy99.pdf. https://doi.org/10.28945/479

Lisenkova, K., Mcquaid, R. W., \& Wright, R. E. (2010). Demographic change and labour markets. Twenty-First Century Society, 5(3), 243-259. https://doi.org/10.1080/17450144.2010.480828 
Luci-Greulich, A., \& Thevenon, O. (2013). The Impact of Family Policies on Fertility Trends in Developed Countries. European Journal of Population, 29(4), 387-416. Available from internet: https://www.researchgate.net/publication/ 254417903_The_Impact_of_Family_Policies_on_Fertility_Trends_in_Developed_Countries. https://doi.org/10.1007/s10680-013-9295-4

ManpowerGroup. (2019). Plany migracyjne pracownikow $\mathrm{z}$ Ukrainy. Available from internet: https://www.manpowergroup.pl /wp-content/uploads/2019/...raport_PL_.pdf.

Masi, A. C. (2019). Migration and Job Mobility: Some Contemporary Lessons from Sidney Goldstein's Patterns of Mobility. In: C. Goldscheider (Ed.), Migration, Population Structure, and Redistribution Policies, 33(60), chapter 2. https://doi.org/10.4324/9780429037900-2

McDonald, P., \& Kippen, R. (2001). Labor supply prospects in 16 developed countries, 2000-2050. Population and Development Review, 27(1), 1-32. Available from internet: https://www.researchgate.net/publication/246636134_ Labour_supply_prospects_in_16_developed_countries. https://doi.org/10.1111/j.1728-4457.2001.00001.X

Mester, L. (2018). Demographics and Their Implications for the Economy and Policy. Cato Journal, 38(2), $399-413$. Available from internet: https://www.cato.org/sites/cato.org/files/serials/files/cato-journal/2018/5/cj-v38n2-6.pdf.

Mecina, J. (2013). Niewykorzystane zasoby. Nowa polityka rynku pracy. Uniwersytet Warszawski, Warszawa.

Migracje zarobkowe Polakow. (2018). Raport Work Service S.A.

Nilsson, K., Hydbom, A. R., \& Rylander, L. (2011). Factors influencing the decision to extend working life or to retire', Scandinavian Journal of Work Environment and Health, 37(6), 473-480. Available from internet: https://www.sjweh.fi/show_abstract.php?abstract_id=3181. https://doi.org/10.5271/sjweh.3181

OECD. (2018). Ageing and Employment Policies. Available from internet: http://www.oecd.org/employment/ ageingandemploymentpolicies.htm.

Oreshkin, M. S. (2018). Prospects of economic policy. Ekonomicheskaya Politika, 13(3), 8-27. https://doi.org/10.18288/ 1994-5124-2018-3-01

Pena-Casas, R. (2017). An ageing active population in Europe: challenges, policies and practices (Chapter 9). In: Social policy in the European Union: state of play 2017 (pp. 181-199). Available from internet: https://www.etui.org/Publications2/Books/Social-policy-in-the-European-Union-state-of-play-2017.

Pocius, A., \& Gruzevskis, B. (2019). Lietuvos demografines tendencijos iki 2030 metų. Lietuvos Pramoninku Konfederacija, Vilnius. Available from internet: http://www.lpk.lt/wp-content/uploads/2019/04/B.Gru\%C5\%BEevskis-Darbo-rinkos-tyrim\%C5\%B3-instituto-vadovas-Lietuvos-demografin\%C4\%97s-tendencijosiki-2030-met\%C5\%B3.pdf.

Pocius, A., \& Okuneviciute Neverauskiene, L. (2017). Lietuvos darbo rinkos regioninių rodiklių diferenciacija demografiniu pokyciu kontekste. In Darbo rinkos pokyciai: problemos ir galimybes. Lietuvos Socialine Raida, 6, 2453. Available from internet: http://www.uwb.lt/wp-content/uploads/2018/11/2017-Lietuvos-socialine-raidagalutinis.pdf.

Polska Agencja Inwestycji i Handlu S. A. (2018). Litwa. Przewodnik po rynku. Warszawa. Available from internet: https://www.paih.gov.pl/publikacje/eksport.

Rocznik Statystyczny Rzeczypospolitej Polskiej 2014. (2015). Glowny Urzad Statystyczny. Warszawa.

Rocznik Statystyczny Rzeczypospolitej Polskiej 2018. (2019). Glowny Urzad Statystyczny. Warszawa.

Sinn, H. W. (2003). Das demografische Defizit. In: Ch. Leipert (Ed.), Demographie und Wohlstand. Opladen: Leske + Budrich (pp. 57-88). Available from internet: http://www.hanswernersinn.de/dcs/sinn-das-demographische-defizitleipert-leske-2003.pdf. https://doi.org/10.1007/978-3-663-09577-4_4

Tucas, R. (2018). Lietuvos gyventoju amziaus demografines strukturos kaitos prognoze 2017-2021 m. Vilniaus Universitetas - Lietuvos Svietimo ir Mokslo Ministeria. Vilnius. Available from internet: https://www.smm.lt/uploads/documents/naujienos/kalbos_pranesimai/Tucas_R_Demografines_prognozes_SMM_20 18_01_18.pdf.

Tukhashvili, M. (2018). Retrospective Comprehension of Post-Soviet Georgia's Population Migration. Bulletin of the Georgian National Academy of Sciences, 12(1), 175-182. Available from internet: http://science.org.ge/bnas/t12n1/28_Tukhashvili.pdf.

Tuomi, K., Ilmarinen, J., Jahkola, A., Katajarinne, L., \& Tulkki, A. (2001). Arbeitsbewaltigungsindex, Work Ability Index (ABI, WAI). Bundesanstalt fur Arbeitsschutz und Arbeitsmedizin, Bremerhaven. Available from internet: http://www.assessment-info.de/assessment/seiten/datenbank/vollanzeige/vollanzeige-de.asp?vid=436\#top. 
Vandenbroek, P. (2018). Underemployment statistics: a quick guide. Research Paper Series, 19, 1-7. Available from internet: https://parlinfo.aph.gov.au/parlInfo/download/library/prspub/5250701/upload_binary/5250701.pdf.

World Economic Outlook. (2004). The Global Demographic Transition, International Monetary Fund, Washington DC. Available from internet: https://www.imf.org/en/Publications/WEO/Issues/2016/12/31/The-Global-DemographicTransition.

Zimmermann, K. F., Bonin, H., Hinte, H., \& Fahr, R. (2007). Immigration Policy and the Labor Market: The German Experience and Lessons for Europe. Springer-Verlag Berlin Heidelberg. https://doi.org/10.1007/978-3-540-68382-7

\section{Authors' biographies}

Dr Magdalena Wysocka is assistant professor at the Department of Economic Policy, Faculty of Economic Sciences, University of Warmia and Mazury in Olsztyn. She has many years of professional experience acquired in Telekomunikacja Polska, TP - France Telekom and Orange Customer Service. Co-executor of research and diagnostic tasks as well as the expert opinions in the field of enterprise restructuring, the labour market and corporate social responsibility

The article has been reviewed.

Received in January 2020; accepted in February 2021. 